2013 年志方メダル受賞記念総説

Award Review Article, 2013 Shikata Medal

\title{
Electroanalytical Study of Actinide Ions
}

\author{
Yoshihiro Kitatsuji \\ Sector of Nuclear Science Research, Nuclear Science and Engineering Center, \\ Japan Atomic Energy Agency, Tokai, Ibaraki 319-1195, Japan
}

Received April 11, 2014

\begin{abstract}
Transfer reactions at the interface of aqueous/organic solutions and redox reactions of actinide ions, such as $\mathrm{U}, \mathrm{Np}$ and $\mathrm{Pu}$, were investigated electrochemically as fundamental studies for the development of separation and speciation of such ions. A method to investigate ion transfer at a liquid/liquid interface based on controlled potential electrolysis and radioactivity measurement was developed and applied to determine standard ion transfer potential and complex formation constant of facilitated actinide ions transfer with an ionophore in the organic phase. A separation method was developed on the basis of the fundamental ion transfer data. Electrode redox reactions of actinide ions were also investigated. A mediator reaction and electrocatalysis were found to be involved in the reduction processes of actinide ions. In addition, a method to control the valence of actinide ions was successfully developed.
\end{abstract}

Keywords: actinide, liquid/liquid interface, ion transfer, reduction mechanism, valence control

\section{Introduction}

Among actinide (abbreviated as An in chemical notation) ions, $\mathrm{U}, \mathrm{Np}$, and $\mathrm{Pu}$, which are the most important elements for nuclear power, exist as trivalent to hexavalent ions in an aqueous solution (rarely $\mathrm{Np}$ (VII) in a basic solution). Interactions of these ions with other species, such as complex and ion-pair formation, significantly differ depending on the valence of the ion. Consequently, understanding and controlling the state of the ion in a solution is necessary for precise analysis and selective separation. Although An ions are successively reduced or oxidized between trivalent and hexavalent forms, the redox reactions are not simple; some are electrochemically irreversible, large overpotentials are observed in some cases, and redox potentials are significantly affected by complex formation. Transfer reactions of An ions at the interface of aqueous (W)/organic (O) solutions are also interesting because they are elementary processes of distribution of the ions between two phases of solvent extraction, which is widely employed or investigated to separate actinides. Electroanalysis is promising for the development of precise adjustments of the oxidation state or transfer at the interface because the reaction is expected to be controlled by applied potential. Therefore, a fundamental study can lead to the development of a 
novel separation and speciation method for actinides. Fundamental and applicable aspects of electrochemical studies of An ions at liquid/liquid and liquid/solid interfaces are summarized in this study.

\section{Actinide transfer by controlled potential electrol- ysis at the $W / O$ solutions interface}

An ions form a stable complex in $\mathrm{O}$ solution and can be extracted to $\mathrm{O}$ phase using many types of extractants. Facilitated transfers of An ions have been studied by polarography at the interface between two immiscible electrolyte solutions (PITIES), which will be described later. However, An ions are so hydrophilic that the transfer reactions are difficult to observe by conventional electrochemical methods because most An ions can only stably dissolve in an acid solution. In highly concentrated acidic solutions, the transfer currents of An ions inevitably overlap with the residual current of coexisting $\mathrm{H}^{+}$ions. To solve this problem, the development of a method based on measurement of radioactivity in two phases rather than the transfer current was attempted to investigate actinide transfer at a W/O solutions interface $^{1)}$. The procedure was as follows: controlled potential electrolysis at a $\mathrm{W} / \mathrm{O}$ solutions interface (CPEITIES) was performed to attain ion transfer equilibrium using a bulk electrolysis cell, as illustrated in Fig. 1; the amount of ion transfer was determined by radioactivity measurement, and the relation between applied potential $\left(E_{\text {app }}\right)$ and the distribution ratio $(D)$ of the ion was plotted. Usually, a fairly long time is required to achieve electrolysis equilibrium at the $\mathrm{W} / \mathrm{O}$ solutions interface due to the small ratio of interfacial area to the volume of two phases. To attain equilibrium more efficiently, a stirring rod was used to stir the W/O solutions interface, as shown in Fig. 1. As a result, the time required to attain electrolysis equilibrium was successfully reduced from more than $4 \mathrm{~h}$ to $20 \mathrm{~min}$.

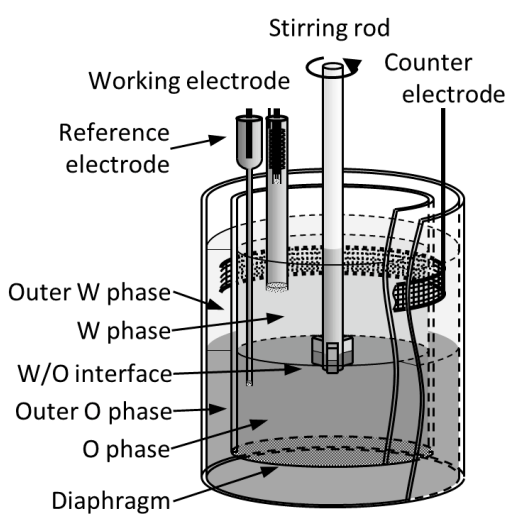

Fig. 1 Apparatus for controlled potential electrolysis at $\mathrm{W} / \mathrm{O}$ solutions interface.

The standard ion transfer potential $\left(E^{0}\right)$ can be determined from the plot of the relationship between $E_{\text {app }}$ and $D$ of the ions transferred by electrolysis in both phases after attaining equilibrium. The method is applicable to ion transfers that compete with other ions, such as supporting electrolytes. Furthermore, radioactivity measurement is effective for low ion concentration.

When the ion transfer reaction between $\mathrm{W}$ and $\mathrm{O}$ solutions is at equilibrium by controlled potential electrolysis, the distribution ratio of the ion is defined by the applied potential based on the Nernst equation as follows.

$$
\begin{aligned}
& E_{\mathrm{app}}=E^{\circ}+(R T / z F) \ln \left(\alpha_{\mathrm{O}} / \alpha_{\mathrm{W}}\right) \\
& =E^{\circ}+(R T / z F) \ln \left(\gamma_{\mathrm{O}} / \gamma_{\mathrm{W}}\right)+(R T / z F) \ln D
\end{aligned}
$$

where $R, T, z$, and $F$ denote the gas constant, absolute temperature, electric charge, and the Faraday constant, respectively.

Results of $\mathrm{UO}_{2}{ }^{2+}$ and $\mathrm{Am}^{3+}$ transfer at the interface between $\mathrm{W}$ and nitrobenzene (NB) phases are shown in Fig. 2 as an example of CPEITIES measurement. Linear relations between $E_{\text {app }}$ and $\log$ $D$ of the ions were obtained at a potential less than $+0.32 \mathrm{~V}$. The $E^{0}$ of ion transfer is determined by the extrapolation of the linear portion to the potential at which $D=1$. 


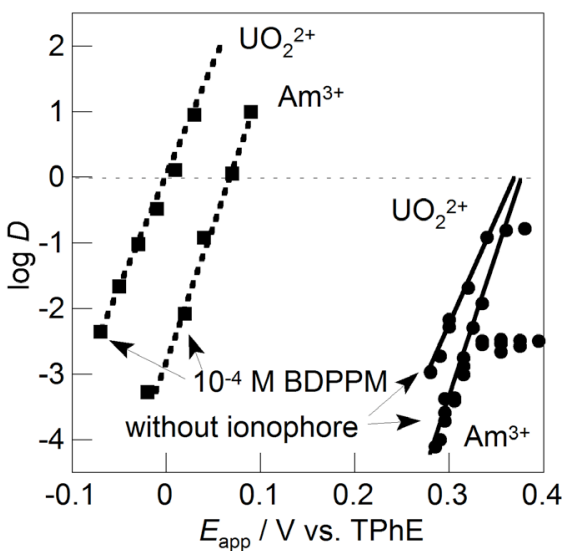

Fig. 2. $\log D$ versus $E_{\text {app }}$ plots for the transfer of $\mathrm{UO}_{2}{ }^{2+}$ and $\mathrm{Am}^{3+}$ with and without BDPPM. W: $0.05 \mathrm{M} \mathrm{MgCl}_{2}$, pH 3.0. NB: $0.05 \mathrm{M}$ THepATFPB (ref. 1).

\section{Determination of $\Delta G_{\mathrm{tr}}{ }^{0}$ of $\mathrm{An}$ ions}

To understand the ion transfer reaction at the $\mathrm{W} / \mathrm{O}$ solutions interface, solvation (hydration in the $\mathrm{W}$ phase) of the ion in solutions, complex formation of the ion with ligand, and ion-pair formation between the ion and counter ions should be determined quantitatively. As the standard Gibbs energy for the transfer of an ion $\left(\Delta G_{\mathrm{tr}}{ }^{0}\right)$ shows the difference between the hydration and solvation energies in both solution phases, the determination of $\Delta G_{\mathrm{tr}}{ }^{0}$ of An ions will provide the necessary data for the solvation of the transferred ions.

An attempt was made to determine the $\Delta G_{\mathrm{tr}}{ }^{0}$ of An ions of various oxidation states using the by partition method ${ }^{2,3)}$ and CPEITIES, ${ }^{1)}$ as described previously. Figure 3 shows the $\Delta G_{\mathrm{tr}}{ }^{0}$ of trivalent to hexavalent $\mathrm{U}, \mathrm{Np}$, and $\mathrm{Pu}$ ions between $\mathrm{W} / \mathrm{O}$ phases. Here five types of organic solvents having relatively high permittivity were employed as the $\mathrm{O}$ phase (i.e., NB, 1,2-dichloroethane, benzonitrile, acetophenone, and 2-nitrophenyl octyl ether). The ion pair formations of pentavalent and hexavalent ions were corrected on the basis of formation constants

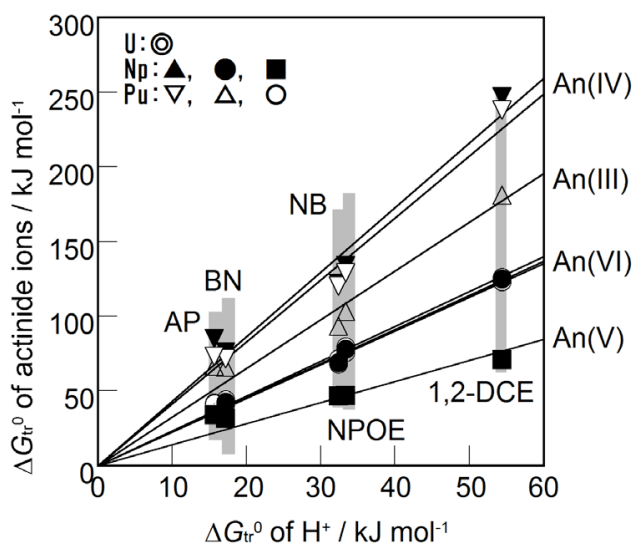

Fig. 3. Relationship between $\Delta G_{\mathrm{tr}}{ }^{0}$ of actinide ion and that of $\mathrm{H}^{+}$(ref. 2).

determined by conductivity measurements.

The values indicated that $\Delta G_{\mathrm{tr}}{ }^{0}$ values for the same oxidation state were similar irrespective of the type of $\mathrm{O}$ solutions. The $\Delta G_{\mathrm{tr}}{ }^{0}$ values of $\mathrm{NpO}_{2}{ }^{+}$ were much larger than those for other An ions divided by the electric charge $(z)$ or $\Delta G_{\mathrm{tr}}{ }^{0}$ of $\mathrm{H}^{+}$ Thus, $\Delta G_{\mathrm{tr}}{ }^{0}$ values for $\mathrm{NpO}_{2}{ }^{+}$with any organic solvents investigated are considered to be particularly large. The pentavalent $\mathrm{Np}$ ion is known to be hardly extracted into the organic solvent due to weak complex formation with any ligand. However, it can be concluded that the particularly high hydrophilic nature is also a reason for its poor extractability. In addition, $\Delta G_{\mathrm{tr}}{ }^{0}$ of An ions was found to be almost proportional to $\Delta G_{\mathrm{tr}}{ }^{0}$ of $\mathrm{H}^{+}$ regardless of the type of An ions. This suggests that solvations of An ions in various oxidation states in $\mathrm{W}$ and various $\mathrm{O}$ solutions that control $\Delta G_{\mathrm{tr}}{ }^{0}$ are not unique. Therefore, it is considered that An ions are partly hydrated even after transfer to $O$ phase and that the ion-solvent interaction in $\mathrm{O}$ phase is through water molecules.

\section{Facilitated transfer of An ions}

Several types of ligands (e.g., phosphine oxide 
derivatives) were employed as an ionophore to facilitate the transfer of An ions. ${ }^{4-6)}$ The transfer of trivalent and hexavalent $\mathrm{An}$ ions from $\mathrm{W}$ to $\mathrm{O}$ phases was found to be facilitated by (bis(diphenyl phosphoryl) methane) (BDPPM), which was added to $O$ solution. Plots of $D$ versus $E_{\text {app }}$ for facilitated transfer of $\mathrm{UO}_{2}{ }^{2+}$ and $\mathrm{Am}^{3+}$ in the presence of $10^{-4}$ M BDPPM measured by CPEITIES are shown as broken lines in Fig. 2. The ion transfer potentials were determined from the plots. The shift of the ion transfer potential with and without an ionophore was attributed to the facilitation of the transfer by the complex formation of an An ion and a ligand. The composition of an actinide complex formed in $\mathrm{O}$ solution and the complex formation constant was estimated on the basis of the difference of ion transfer potentials.

The kinetics of a facilitated transfer of An ions with BDPPM was investigated using PITIES. The transfer current wave of $\mathrm{UO}_{2}{ }^{2+}$ and $\mathrm{Pu}^{3+}$ appeared to be quasi-irreversible. The adsorption of the species at the W/O solutions interface was investigated on the basis of the results of drop-time measurements of a dropping aqueous solution electrode. Figure 4 shows the drop time and the applied potential relationship during the polarographic measurement of $\mathrm{UO}_{2}{ }^{2+}$ transfer facilitated by $\mathrm{BDPPM}^{4)}$. The drop time decreased with the addition of BDPPM to $\mathrm{O}$ solution and increased slightly during $\mathrm{UO}_{2}{ }^{2+}$ transfer to $\mathrm{O}$ phase. It could be concluded that the transfer of An ions from $\mathrm{W}$ to $\mathrm{O}$ phases consisted of three steps: (1) adsorption of BDPPM at the interface; (2) complex formation of the An ion and the ionophore adsorbed at the interface; (3) desorption of the complex from the interface through the transfer of the actinide ion.

\section{Separation based on ion transfer}

Based on ion transfer data, a novel separation method (i.e., electrolytic solvent extraction) was developed. In this method, the ion was selectively

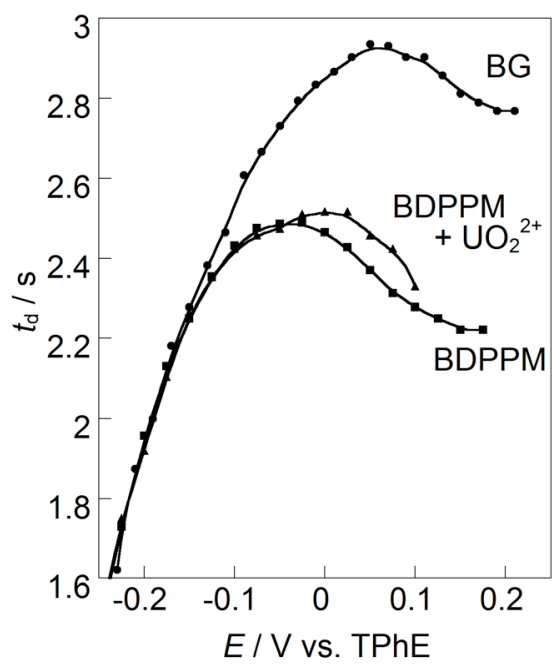

Fig. 4. Drop-time versus potential relations during polarographic measurements for facilitated transfer of $\mathrm{UO}_{2}{ }^{2+}$ by BDPPM (ref. 4).

transferred from $\mathrm{W}$ to $\mathrm{O}$ phases utilizing the differences in ion transfer potential. By using a CPEITIES cell, described above, it was found that $\mathrm{UO}_{2}{ }^{2+}$ could be separated from $\mathrm{Am}^{3+}$ with a separation factor of more than $10^{3}$ when $E$ was -0.035 V (Fig. 2). ${ }^{1)}$

To improve the efficiency and speed of electrolytic solvent extraction, a flow electrolysis cell for rapid ion transfer (FECRIT) ${ }^{7)}$ was applied to the separation of An ions. The cell was composed of a porous Teflon tube, a silver wire inserted into the tube, and a platinum wire placed outside the tube. The tube was immersed in $\mathrm{O}$ solution, and $\mathrm{W}$ solution containing An ions flowed through the narrow gap between the tube and silver wire. All of the target An ions could be transferred to $\mathrm{O}$ phase by electrolysis until the solution exited through the tube. $\mathrm{UO}_{2}{ }^{2+}$ was successfully separated from other An ions and lanthanide ions within 1 min by using (bis(diphenylphosphoryl) ethane) (BDPPE) as the ionophore. ${ }^{8)}$ Although the An ions in the same oxidation state, such as $\mathrm{NpO}_{2}{ }^{2+}$ and $\mathrm{PuO}_{2}{ }^{2+}$, could not be separated, a successive separation method for 


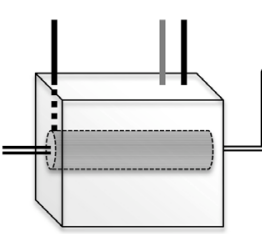

Column electrode

$\mathrm{UO}_{2}{ }^{2+}$

$\mathrm{NpO}_{2}{ }^{2+} \rightarrow \mathrm{NpO}_{2}^{+}$

$\mathrm{PuO}_{2}{ }^{2+} \rightarrow \mathrm{Pu}^{3+}$

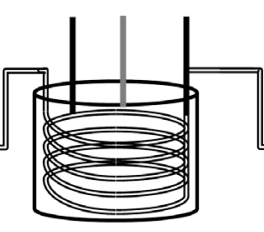

FECRIT

Extraction of $\mathrm{UO}_{2}{ }^{2+}$ by BDPPE

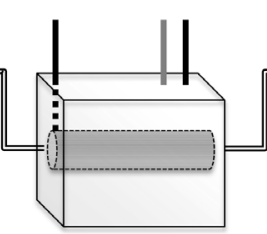

$$
\mathrm{NpO}_{2}^{+} \rightarrow \mathrm{NpO}_{2}^{+}
$$$$
\mathrm{Pu}^{3+} \rightarrow \mathrm{Pu}^{4+}
$$

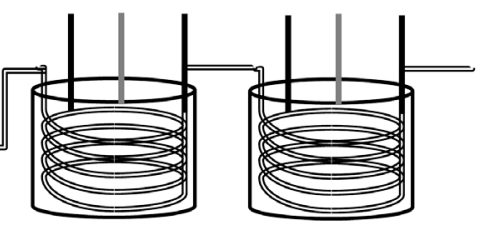

Extraction of $\mathrm{NpO}_{2}{ }^{2+}$ by BDPPE

Extraction of $\mathrm{Pu}^{4+}$ by BDPPM

Fig. 5. Schematic diagram of the flow electrolytic solvent extraction system for actinide separation.

$\mathrm{U}, \mathrm{Np}$, and Pu using a column electrode for valence control, and FECRIT was proposed (Fig. 5). Valence control will be described in a subsequent section.

It is thought that a large separation factor achieved by the precise control of the applied potential based on ion transfer data and rapid transfer of the ions by flow electrolysis would contribute to the development of a practical separation method.

\section{Pu ion-selective electrode}

Actinide ion transfer that satisfies the Nernst relation can be applied to develop an ion-selective electrode (ISE). Based on the ion transfer data of $\mathrm{Pu}^{3+}$ facilitated by BDPPM, a $\mathrm{Pu}^{3+}$-ISE was designed. ${ }^{5)}$ NB containing BDPPM and a $\mathrm{Pu}^{3+}$-BDPPM complex was prepared by solvent extraction and employed as a $\mathrm{Pu}^{3+}$-ISE liquid membrane. Figure 6 shows the ISE potential generated between the ISE and a reference electrode plotted against the concentration of $\mathrm{Pu}^{3+}\left(c_{\mathrm{Pu}(\mathrm{III})}\right)$ in a test solution of a $10^{-3} \mathrm{M} \mathrm{HCl}$ medium. A slope of $19 \mathrm{mV}$ per decade of $c_{\mathrm{Pu}(\mathrm{III})}$, which is in agreement with the theoretical Nernstian response, was obtained. The proposed ISE exhibited the Nernstian response from $1 \times 10^{-7}$ to $1 \times 10^{-2} \mathrm{M} \mathrm{Pu}^{3+}$ in a $10^{-3}$ $\mathrm{M} \mathrm{HCl}$ medium.

An $\mathrm{Eu}^{3+}$-ISE was developed and used to estimate complex formation constants of lanthanide

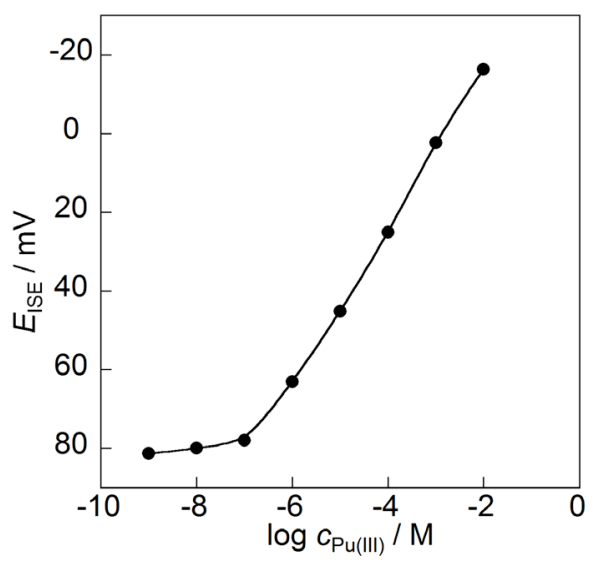

Fig. 6. Potential measured at $\mathrm{Pu}^{3+}$-ISE. Test solution: $10^{-3} \mathrm{M} \mathrm{HCl}$ (ref. 5).

and organic ligands. ${ }^{9)}$ The composition of the $\mathrm{Eu}^{3+}$-ISE was similar to that of the $\mathrm{Pu}^{3+}$-ISE.

\section{Electrode redox reaction of An ions}

$\mathrm{U}, \mathrm{Np}$, and $\mathrm{Pu}$ exist as trivalent to hexavalent ions in acids such as $\mathrm{HCl}, \mathrm{HNO}_{3}$, and $\mathrm{HClO}_{4}$. It is well known that $A n(I I I)$ and $A n(I V)$ are hydrated ions $\left(\mathrm{An}^{3+}\right.$ and $\mathrm{An}^{4+}$, respectively), while $\mathrm{An}(\mathrm{V})$ and $\mathrm{An}(\mathrm{VI})$ form dioxo ions $\left(\mathrm{AnO}_{2}{ }^{+}\right.$and $\mathrm{AnO}_{2}{ }^{2+}$, respectively). Although the redox of $\mathrm{An}^{4+} / \mathrm{An}^{3+}$ and $\mathrm{AnO}_{2}{ }^{2+} / \mathrm{AnO}_{2}{ }^{+}$couples in various types of acid solutions have been well studied and reported to be reversible or quasi-reversible reactions ${ }^{10)}$, the investigation of electrode redox reactions of 
$\mathrm{AnO}_{2}{ }^{+} / \mathrm{An}^{4+}$ couples has been limited. Electrode reactions of $\mathrm{AnO}_{2}^{+} / \mathrm{An}^{4+}$ couples include the formation or breaking of $\mathrm{An}-\mathrm{O}$ bonds; consequently, they are so irreversible that the voltammetric observation of the redox current is difficult. The detailed clarification of the reaction mechanisms of the irreversible redox of An ions can provide information that would contribute to the development of a reliable method to control the oxidation state of An ions.

\section{Reduction processes of irreversible reduction of $\mathbf{N p}(\mathrm{V})$}

Bulk electrolysis was employed to investigate the irreversible reduction of $\mathrm{NpO}_{2}{ }^{+11)}$ The reduction currents of $\mathrm{NpO}_{2}{ }^{2+}$ and $\mathrm{NpO}_{2}{ }^{+}$in $1 \mathrm{M}$ $\mathrm{HClO}_{4}$ at a gold gauze electrode during controlled potential electrolysis were compared. The results are shown in Fig. 7. The reduction current of $\mathrm{NpO}_{2}{ }^{2+}$ by applying $+0.6 \mathrm{~V}$ versus SSE decreased
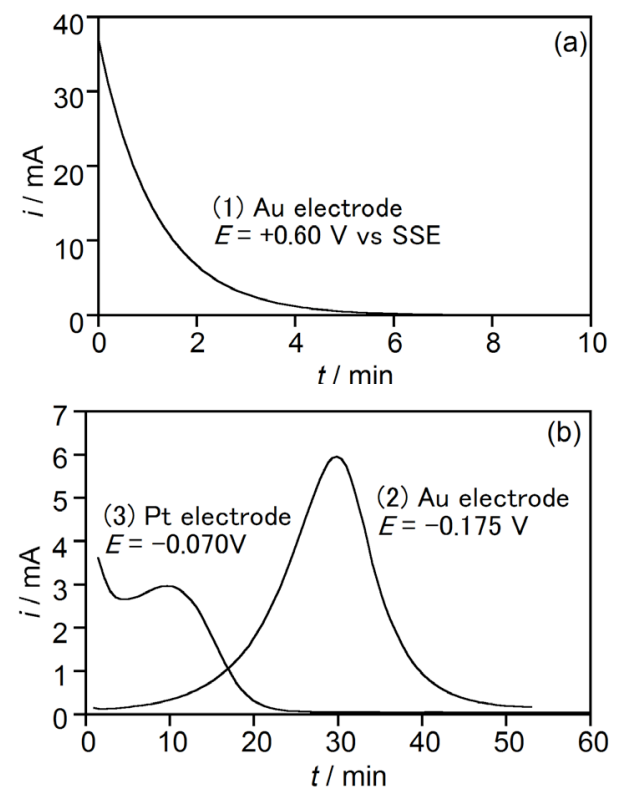

Fig. 7. Current-time curve observed by controlled potential electrolysis at a gold or platinum electrode for reduction of (a) $\mathrm{NpO}_{2}{ }^{2+}$ and (b) $\mathrm{NpO}_{2}{ }^{+}$in $1 \mathrm{M}$ $\mathrm{HClO}_{4}$ (ref. 11). exponentially with time (Curve 1) and reached the background level observed in the absence of $\mathrm{NpO}_{2}{ }^{2+}$ after $20 \mathrm{~min}$. This reduction behavior is consistent with a first-order reaction, i.e., the current decays exponentially with time during electrolysis. The electric charge during electrolysis was the same as the theoretical value for the one-electron reduction of $\mathrm{NpO}_{2}{ }^{2+}$ to $\mathrm{NpO}_{2}{ }^{+}$:

$\mathrm{NpO}_{2}{ }^{2+}+\mathrm{e}^{-} \rightarrow \mathrm{NpO}_{2}{ }^{+}$.

On the other hand, unique reduction behavior was observed when $\mathrm{NpO}_{2}^{+}$was electrolyzed at a gold electrode by applying $-0.175 \mathrm{~V}$ (Curve 2 in Fig. 7b). At the beginning of electrolysis, the current was close to the background level. It increased gradually for approximately $30 \mathrm{~min}$ and then decreased to the background level. After the completion of bulk electrolysis, $\mathrm{Np}^{3+}$ and $\mathrm{Np}^{4+}$ were produced in the electrolyzed solution. The electric charge during electrolysis agreed with the theoretical value for the mixture solution of $\mathrm{Np}^{3+}$ and $\mathrm{Np}^{4+}$ whose concentrations were determined by spectrophotometry. Although the reduction current of $\mathrm{NpO}_{2}{ }^{+}$could not be observed by voltammetry at a gold electrode, $\mathrm{NpO}_{2}{ }^{+}$was reduced to $\mathrm{Np}^{4+}$ or $\mathrm{Np}^{3+}$ by controlled-potential bulk electrolysis.

The reduction mechanism of $\mathrm{NpO}_{2}^{+}$to $\mathrm{Np}^{4+}$ and $\mathrm{Np}^{3+}$ can be explained by the combination of the electrode reduction of $\mathrm{Np}^{4+}$ to $\mathrm{Np}^{3+}$ (Eq. 3) and the electron exchange reaction between $\mathrm{Np}^{3+}$ and $\mathrm{NpO}_{2}{ }^{+}$in a bulk solution (Eq. 4).

$\mathrm{Np}^{4+}+\mathrm{e}^{-} \rightarrow \mathrm{Np}^{3+}$

$\mathrm{NpO}_{2}^{+}+\mathrm{Np}^{3+}+4 \mathrm{H}^{+} \rightleftarrows 2 \mathrm{~Np}^{4+}+2 \mathrm{H}_{2} \mathrm{O}$

That is, $\mathrm{Np}^{4+} / \mathrm{Np}^{3+}$ acts as a mediator for the reduction of $\mathrm{NpO}_{2}^{+}$. Here the initial solution of $\mathrm{NpO}_{2}{ }^{+}$contains a very small amount of $\mathrm{Np}^{4+}$, which was produced by the disproportionation of $\mathrm{NpO}_{2}{ }^{+}$ (Eq. 5). 
$2 \mathrm{NpO}_{2}^{+}+4 \mathrm{H}^{+} \rightleftarrows \mathrm{Np}^{4+}+\mathrm{NpO}_{2}^{2+}+2 \mathrm{H}_{2} \mathrm{O}$

The coexisting $\mathrm{Np}^{4+}$ becomes a trigger for the mediator reaction.

This reduction mechanism of $\mathrm{NpO}_{2}{ }^{+}$occurs at any electrode material, such as carbon and platinum. The reaction proceeds as a matter of course at the potential at which $\mathrm{Np}^{4+}$ is reduced to $\mathrm{Np}^{3+}$, and reaction rates increase at more negative potentials up to $-0.175 \mathrm{~V}$.

A peculiar reduction was observed when a platinum gauze was used as the working electrode (Curve 3, Fig. 7b). Although a current peak was observed at approximately $10 \mathrm{~min}$ of electrolysis time, a relatively large Faradaic current was observed even at the beginning of electrolysis. It should be noted that the potential of electrolysis was more positive than that of electrolysis at a gold electrode (Curve 2, Fig. 7b).

$\mathrm{H}^{+}$is reduced, forming adsorbed hydrogen on the platinum surface, when the applied potential is more negative than approximately $0 \mathrm{~V}$. At this potential range, a small current resulting from the reduction of $\mathrm{NpO}_{2}^{+}$was observed by voltammetry. Therefore, it is suggested that the hydrogen atom on the electrode surface reduces $\mathrm{NpO}_{2}^{+}$.

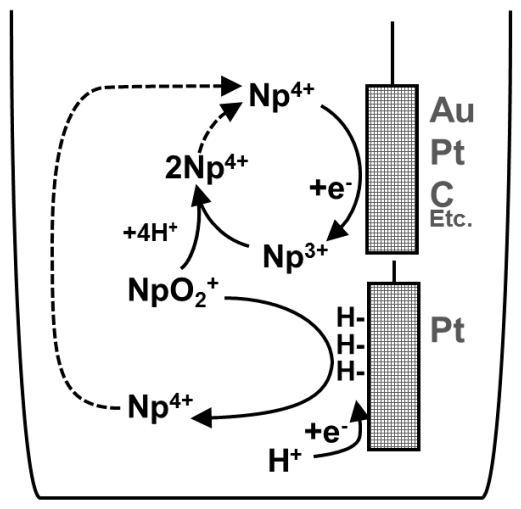

Fig. 8. Two reaction schemes for $\mathrm{NpO}_{2}{ }^{+}$reduction by bulk electrolysis.
$\mathrm{NpO}_{2}^{+}+\mathrm{Pt}-\mathrm{H}+3 \mathrm{H}^{+} \rightleftarrows \mathrm{Np}^{4+}+2 \mathrm{H}_{2} \mathrm{O}+\mathrm{Pt}-$

The $\mathrm{Np}^{4+}$ produced by the reaction shown in Eq. 6 functions as an electron transfer mediator to reduce $\mathrm{NpO}_{2}^{+}$(Eqs. 3 and 4), similar to the reaction at a gold electrode. These two $\mathrm{NpO}_{2}^{+}$reduction schemes are illustrated in Fig. 8. The combination of the mediator reaction of $\mathrm{Np}^{4+} / \mathrm{Np}^{3+}$ and the electrocatalytic reduction of the platinum electrode resulted in the rapid formation of $\mathrm{Np}^{4+}$ by bulk electrolysis with a platinum electrode.

\section{Electrolytic control of the oxidation state of An ions}

Since it is not necessary to add any reagents and as electrolysis potential can be controlled precisely and freely, controlled potential electrolysis is a promising method for the adjustment of the oxidation state of ions. Flow electrolysis enables the rapid control of ion valence, even in a slow electrode reaction because the ions are repeatedly electrolyzed as they flow through the flow path. The author employed flow electrolysis with glassy carbon (GC) column electrodes for the precise and selective control of the oxidation state of An ions. ${ }^{12)}$

The column electrode was a working electrode comprising a bundle of very thin GC fibers tightly packed in a cylindrical electrolytic diaphragm cell of porous glass. Fabrication procedures and the pretreatment of GC fiber have been described in the literature. ${ }^{13)}$ Electrolysis is performed by passing the electrolyte solution containing An ions through the narrow paths between the GC fibers.

An example of the electrolysis behavior of An ions by flow electrolysis (current $(I)$-potential $(E)$ curves for the redox of $\mathrm{Np}$ ions in various oxidation state in $1 \mathrm{M} \mathrm{HClO}_{4}{ }^{12)}$ ) is shown in Fig. 9. The curves were charted after correction for the residual current observed in the absence of $\mathrm{Np}$ ions. Here the ordinate of the figure indicates $n$, which is the number of electrons involved in the redox reaction. 


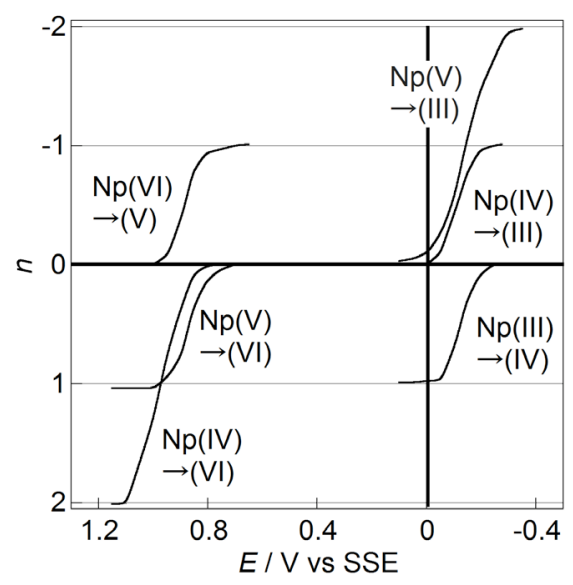

Fig. 9. $I-E$ curves for redox of $\mathrm{Np}$ ions in $1 \mathrm{M}$ $\mathrm{HClO}_{4}$ (ref. 12).

On the flow electrolysis, the limiting current $\left(I_{1}\right)$ is the function of $n, F$, the concentration of the ions (c) and the flow rate of the solution $(f)$.

$$
I_{1}=n F c f
$$

Therefore, $n$ is calculated by dividing the measured $I$ by the product of $F, c$, and $f$.

One-electron redox currents due to $\mathrm{Np}^{4+} / \mathrm{Np}^{3+}$ and $\mathrm{NpO}_{2}{ }^{2+} / \mathrm{NpO}_{2}{ }^{+}$couples are observed at approximately $-0.2 \mathrm{~V}$ and $+0.8 \mathrm{~V}$, respectively. These redox waves show the reversible nature of the reactions. In addition, the two-electron reduction current of $\mathrm{NpO}_{2}{ }^{+}$, which, as described previously, is not clearly observed by voltammetry, can be observed at $-0.2 \mathrm{~V}$ in the $I-E$ curve. This reduction potential is close to that of the reduction of $\mathrm{Np}^{4+}$ to $\mathrm{Np}^{3+}$. This reduction of $\mathrm{NpO}_{2}^{+}$proceeds by a mediator reaction with $\mathrm{Np}^{4+} / \mathrm{Np}^{3+}$, as described above. An oxidation current of $\mathrm{Np}^{4+}$ is observed at approximately $+1.0 \mathrm{~V}$; however, it is overlapped with the residual current and is somewhat unclear.

Based on the $I-E$ curve, electrolytic preparation of $\mathrm{Np}^{3+}, \mathrm{Np}^{4+}, \mathrm{NpO}_{2}{ }^{+}$, and $\mathrm{NpO}_{2}{ }^{2+}$ can be proposed. $\mathrm{Np}^{3+}$ and $\mathrm{NpO}_{2}{ }^{2+}$ can be prepared by single column electrode electrolysis. However, $\mathrm{Np}^{4+}$ and $\mathrm{NpO}_{2}^{+}$ require two-step column electrode electrolysis to adjust the oxidation state, i.e., to prepare $\mathrm{Np}^{4+}$, all $\mathrm{Np}$ is reduced to $\mathrm{Np}^{3+}$ at the first column electrode and then $\mathrm{Np}^{3+}$ is oxidize to $\mathrm{Np}^{4+}$ at the second electrode.

The concentration of $\mathrm{Np}^{4+}, \mathrm{NpO}_{2}^{+}$, and $\mathrm{NpO}_{2}{ }^{2+}$ could be successfully determined by measuring the electrolysis current. The method is applicable to the detection of $\mathrm{Np}^{3+}$; however, $\mathrm{Np}^{3+}$ is not stable in an acid solution.

When a platinum electrode is employed as a working electrode, the reduction overpotential of $\mathrm{NpO}_{2}{ }^{+}$is expected to decrease because of the electrocatalytic reduction, as described previously. The author tried to add an electrocatalytic function to the column electrode. ${ }^{14)}$ Figure 10 shows the effect of platinization on the $I-E$ curve for the reduction of $\mathrm{NpO}_{2}^{+}$at a column electrode with platinized $\mathrm{GC}(\mathrm{Pt} / \mathrm{GC})$ fiber prepared by the electrodeposition of platinum on a GC surface. The overpotential of reduction of $\mathrm{NpO}_{2}^{+}$to $\mathrm{Np}^{4+}$ was significantly decreased relative to the degree of platinization. The reduction-current wave of the $I-E$ curve changed from a one-step two-electron curve at normal GC to successive two-step one-electron waves of $\mathrm{NpO}_{2}^{+} \rightarrow \mathrm{Np}^{4+} \rightarrow \mathrm{Np}^{3+}$ at a $\mathrm{Pt} / \mathrm{GC}$

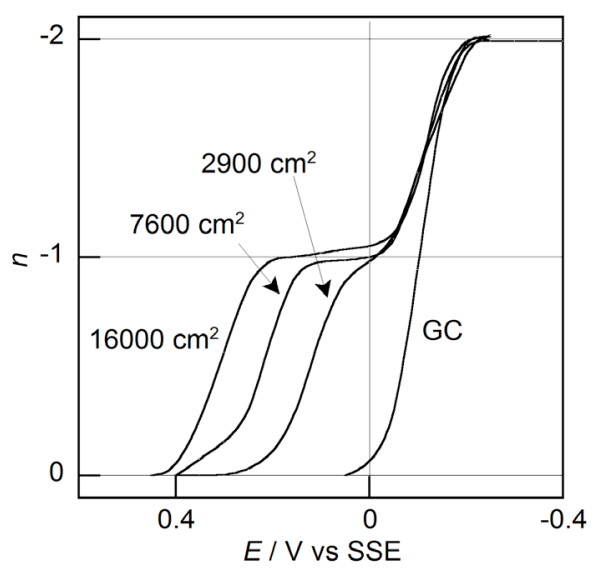

Fig. 10. Effect of the platinized surface area on $I-E$ curves for reduction of $\mathrm{NpO}^{2+}$ (ref. 14). 
electrode. This successive reduction means that preparation of $\mathrm{Np}^{4+}$ can be achieved by electrolysis at approximately $+0.15 \mathrm{~V}$ using only a single column electrode.

The $I-E$ curve for the reduction of $\mathrm{U}, \mathrm{Np}$, and $\mathrm{Pu}$ at normal $\mathrm{GC}$ and $\mathrm{Pt} / \mathrm{GC}$ is compared in Fig. 11. In the case of $\mathrm{Pu}$, the reduction wave of $\mathrm{PuO}_{2}{ }^{2+}$ changed from a two-step wave (i.e., $\mathrm{PuO}_{2}{ }^{2+} \rightarrow$ $\left.\mathrm{PuO}_{2}{ }^{+} \rightarrow \mathrm{Pu}^{3+}\right)$ to a one-step three-electron wave (i.e., $\mathrm{PuO}_{2}{ }^{2+} \rightarrow \mathrm{Pu}^{3+}$ ). This result indicates that the reduction overpotential of $\mathrm{PuO}_{2}^{+}$to $\mathrm{Pu}^{4+}$ was decreased.

The one-step two-electron reduction of $\mathrm{UO}_{2}{ }^{2+}$ to $\mathrm{U}^{4+}$ was observed at the $\mathrm{Pt} / \mathrm{GC}$ electrode as well as
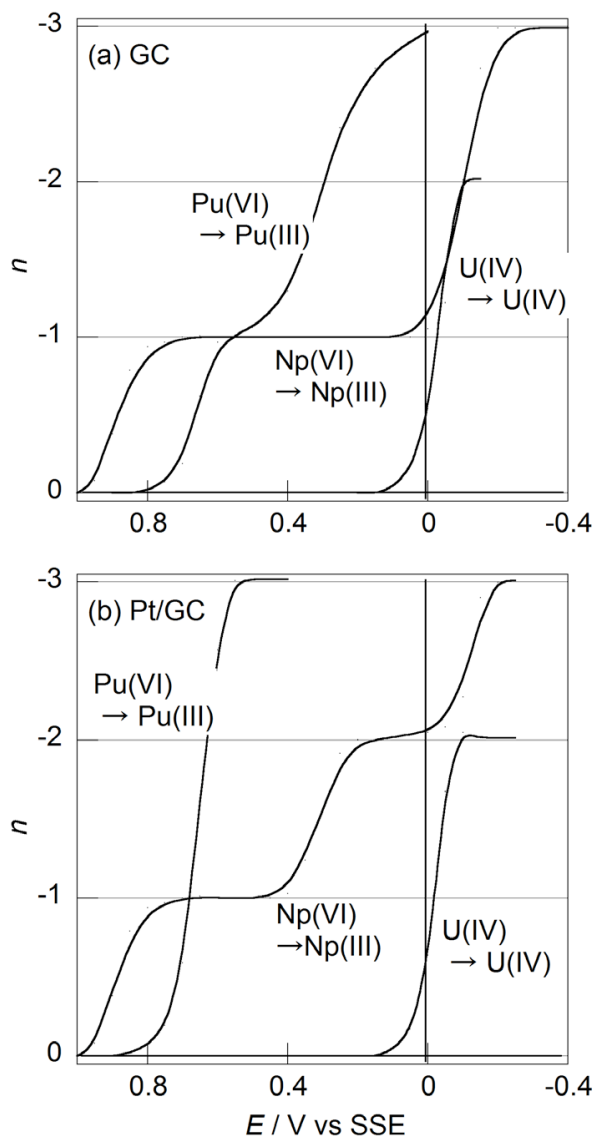

Fig. 11. I-E curves for redox of $\mathrm{U}, \mathrm{Np}$, and Pu ions at a platinized GC fiber electrode (ref. 14). at normal GC. The reduction potential was hardly affected by platinization because the reduction of $\mathrm{UO}_{2}{ }^{+}$results from very rapid disproportionation producing $\mathrm{NpO}_{2}{ }^{2+}$ and $\mathrm{U}^{4+}$.

Based on these unique characteristics of a $\mathrm{Pt} / \mathrm{GC}$ column electrode, the selective adjustment of the valence of An ions can be achieved successfully. When $\mathrm{Pt} / \mathrm{GC}$ electrode is employed, $\mathrm{U}, \mathrm{Np}$, and $\mathrm{Pu}$ ions in different oxidation states (i.e., $\mathrm{UO}_{2}{ }^{2+}, \mathrm{Np}^{4+}$, and $\left.\mathrm{Pu}^{3+}\right)$ can be prepared by electrolysis at +0.15 $\mathrm{V} ; \mathrm{UO}_{2}{ }^{2+}, \mathrm{NpO}_{2}{ }^{+}$and $\mathrm{Pu}^{3+}$ were also prepared at $+0.5 \mathrm{~V}$.

\section{Conclusions}

The electroanalysis of liquid/solid and liquid/liquid electrodes provides useful information about the solution chemistry of An ions.

Elementary processes of the transfer of An ions at a W/O solutions interface and the solvation state of actinide ion after interfacial transfer could be clarified by PITIES and CPEITIES. Fundamental studies of ion transfer were applied to develop a separation method for An ions. The electrochemical method enables precise control with a high separation factor; however, the solvents that can be used with electrolytic solvent extraction are limited. Therefore, in future, the application of the methodology to common organic solvents will be investigated.

With regard to redox reactions of An ions, the irreversible reduction mechanisms of $\mathrm{AnO}_{2}^{+}$have been clarified and a method to control valence was developed. However, the details of the irreversible oxidation process of $\mathrm{An}^{4+}$ are unexplained as yet. Redox reactions of An ions in non-acidic solutions are interesting and significant, because they involve hydrolysis forming a hydroxide complex, a colloid, and a precipitate.

\section{Acknowledgements}

The author would like to thank his co-workers, 
especially Prof. Sorin Kihara and Dr. Zenko Yoshida, for helpful discussions and encouragement.

\section{References}

1) Y. Kitatsuji, Z. Yoshida, H. Kudo, S. Kihara. $J$. Electroanal. Chem. 520, 133-144 (2002).

2)Y. Kitatsuji, T. Okugaki, M. Kasuno, H. Kubota, K. Maeda, T. Kimura, Z. Yoshida, S. Kihara. $J$. Chem. Thermodyn. 43, 844-851 (2011).

3)Y. Yoshida, Z. Yoshida, H. Aoyagi, Y. Kitatsuji, A. Uehara, S. Kihara. Anal. Chim. Acta 452, 149-161 (2002).

4) Y. Kitatsuji, H. Aoyagi, Z. Yoshida, S. Kihara. Anal. Sci. 14, 67-70 (1998).

5) Y. Kitatsuji, H. Aoyagi, Z. Yoshida, S. Kihara. Anal. Chim. Acta 387, 181-187 (1999).

6) M. Ying, Y. Kitatsuji, T. Kimura, Z. Yoshida. J. Nucl. Radiochem. Sci. 2, 11-15 (2001).

7) A. Yoshizumi, A. Uehara, M. Kasuno, Y. Kitatsuji, Z. Yoshida, S. Kihara. J. Electroanal.
Chem. 581, 275-283 (2005).

8) T. Okugaki, Y. Kitatsuji, M. Kasuno, A. Yoshizumi, H. Kubota, Y. Shibafuji, K. Maeda, Z. Yoshida, S. Kihara. J. Electroanal. Chem. 629, 50-56 (2009).

9) T. Sasaki, H. Yoshida, Y. Kitatsuji, I. Takagi, H. Moriyama. Chem. Lett. 40, 870-871 (2011).

10) S. Kihara, Z. Yoshida, H. Aoyagi, K. Maeda, O. Shirai, Y. Kitatsuji, Y. Yoshida. Pure Appl. Chem. 71, 1771-1807 (1999).

11) Y. Kitatsuji, T. Kimura, S. Kihara. $J$. Electroanal. Chem. 641, 83-89 (2010).

12) H. Aoyagi, Y. Kitatsuji, Z. Yoshida, S. Kihara. Anal. Chim. Acta 538, 283-289 (2005).

13) C. Nishihara, H. Kaneko, A. Negishi, T. Hinoue, Y. Kitatsuji, H. Aoyagi, M. Oyama, M. Kasuno, A. Yoshizumi, T. Okugaki, S. Kihara (Editor). Rev. Polarogr. 52, 41-61 (2006).

14) Y. Kitatsuji, T. Kimura, S. Kihara. Electrochim. Acta 74, 215-221 (2012). 